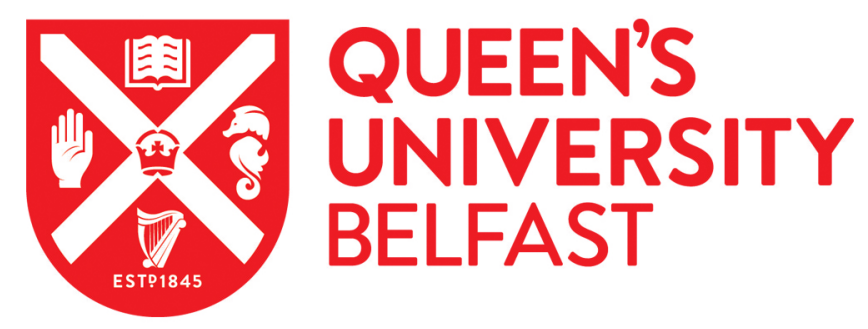

\title{
Who needs evidence? Radical Feminism, the Christian Right and sex work research in Northern Ireland
}

Ellison, G. (2016). Who needs evidence? Radical Feminism, the Christian Right and sex work research in Northern Ireland. In S. Armstrong, J. Blaustein, \& H. Alistair (Eds.), Reflexivity and Criminal Justice: Intersections of Policy, Practice and Research. Palgrave Macmillan.

Published in:

Reflexivity and Criminal Justice: Intersections of Policy, Practice and Research.

\section{Document Version:}

Peer reviewed version

Queen's University Belfast - Research Portal:

Link to publication record in Queen's University Belfast Research Portal

Publisher rights

(C) 2018 The Authors and Editors.

This work is made available online in accordance with the publisher's policies. Please refer to any applicable terms of use of the publisher.

\section{General rights}

Copyright for the publications made accessible via the Queen's University Belfast Research Portal is retained by the author(s) and / or other copyright owners and it is a condition of accessing these publications that users recognise and abide by the legal requirements associated with these rights.

Take down policy

The Research Portal is Queen's institutional repository that provides access to Queen's research output. Every effort has been made to ensure that content in the Research Portal does not infringe any person's rights, or applicable UK laws. If you discover content in the Research Portal that you believe breaches copyright or violates any law, please contact openaccess@qub.ac.uk. 
Who needs evidence? Radical Feminism, the Christian Right and sex work research in Northern Ireland

\section{Graham Ellison}

\section{School of Law}

Queen's University, Belfast

\section{BELFAST}

\section{BT7 1NN}

\section{g.ellison@qub.ac.uk}

\section{Introduction}

This chapter describes my experiences of conducting research on commercial sex ${ }^{1}$ in Belfast, Northern Ireland which was conducted as part of a larger British Academy Leverhulme Trust funded study that examined the policing and legal regulation of commercial sex in Belfast (Northern Ireland) along with three other cities: Manchester (England), Berlin (Germany) and Prague (Czech Republic). ${ }^{2}$ This study provided the first empirical analysis of commercial sex in the jurisdiction and was instrumental in shedding light on prevalence rates for those involved in the industry as well as providing demographic information on the age, nationality and sexual orientation of sex workers along with the sector worked in, whether onstreet or off-street (Ellison, 2015). While academics and researchers are now well attuned to the varieties and differences in the organisation of commercial sex both within and between jurisdictions what is less well studied and understood are the ways in which attitudes to commercial sex are deeply embedded in local political cultures (Ellison, 2015; Zimmerman, 2012). In the chapter I consider my role as a researcher and highlight some of the difficulties that I experienced conducting what was seen as controversial research in the politically, socially and culturally conservative context of Northern Ireland. In this respect, I situate the discussion within the Northern Ireland Assembly's decision to legislate for Lord Morrow's (of the Democratic Unionist Party, henceforth DUP) Human Trafficking \& Exploitation (Further Provisions and Support for Victims) Bill that included a number of provisions to provide support to victims of human trafficking but controversially also included specific provisions to make it a criminal offence to 'pay for the sexual services of a person' (Clause 15) in emulation of the so-called 'Nordic model' of criminalisation of demand. ${ }^{3}$ 
Clause 15 is modelled on developments that originally occurred in the Scandinavian jurisdictions (first Sweden in 1999, then later in Norway and Iceland) and which refers to what is called an 'asymmetric model of criminalisation' whereby the buyer not the seller of sexual services faces legal penalties (Levy, 2014; Scoular, 2004). According to its adherents this model reduces the opportunities for commercial sex and by extension the potential for human trafficking for sexual exploitation (see generally Ekberg, 2004; Farley et al, 2009). However, for its opponents the model has vastly increased the risks to sex workers and has impacted most severely on those migrant (female) sex workers who face deportation from Sweden (Levy, 2014).

The chapter is structured as follows. I begin by providing a summary overview of the hotly contested theoretical terrain of sex work research before moving on to consider how a more reflexive research position can illuminate facets of commercial sex that are not necessarily made apparent in traditional neo-abolitionist research (e.g. see Ekberg, 2004; Farley et al, 2009; Jeffreys, 2008; Barry, 1995). I then discuss the evidence base for the claims made by DUP Members of the Legislative Assembly (henceforth MLAs) and some advocacy organisations that sexual slavery and trafficking for sexual exploitation are rife in Northern Ireland which provided the rationale for introducing sex purchase legislation. The chapter ends with a discussion of the difficulties that I and other researchers faced in researching such a sensitive topic in the Northern Irish context.

\section{Theorising commercial sex}

One of the most contentious research areas in criminology and the social sciences generally concerns that of 'prostitution' or 'commercial sex' (Dewey, 2014; Ryan \& Huschke, 2015; Hammond \& Kingston, 2014; Shaver, 2005). Indeed, as several commentators have noted the decision to engage with commercial sex as a terrain of research also means entering into a 'hotly contested political and ideological terrain' (Dewey, 2014: 4). Even the terminology chosen - 'prostitution' or 'commercial sex' - reflects the a priori ideological, moral or political standpoint of the researcher and as a consequence can lead to particular problems in how we engage reflexively with the subject matter. While space precludes a detailed overview, the landscape of sex work research is dominated by two broad but mutually exclusive positions. First, is a perspective rooted in a strand of radical feminism - what is termed neo-abolitionist feminism (Bernstein, 2007) - that regards all aspects of commercial sex (to include pornography and all forms of adult entertainment) as exploitative and the embodiment of patriarchal 
domination and oppression. Indeed, this particular perspective has been termed the 'oppression paradigm' by Weitzer (2011). Commentators writing in this genre prefer the terms 'prostituted women' or 'women in prostitution' to signify a lack of agency whereby women (men and transgendered individuals are absent from these analyses) are coerced into prostitution, objectified and turned into a commodity to be bought and sold (Ekberg, 2004; Farley et al, 2009; Barry,1995; Jeffreys, 2008). For some prominent neo-abolitionists such as Melissa Farley women cannot consent to commercial sex under any circumstances and as she suggests, 'To the extent that any woman is assumed to have freely chosen prostitution, then it follows that enjoyment of domination and rape are in her nature' (cited in Weitzer, 2006: 34). While some feminist commentators in this genre regard all heterosexual sexual activity - what they term 'penis in vagina sex' (Jeffreys, 2008: 327) - as exploitative, it is prostitution that represents the epitome of exploitation: Indeed, for the radical feminist Kathleen Barry, prostitution is '...the most extreme and crystallised form of all sexual exploitation' (Barry, 1995: 9).

An alternative reading of commercial sex has been termed a 'polymorphous perspective' by Weitzer (2011). This perspective is considerably broader than the 'oppression paradigm' mentioned above insofar as it is anchored in a variety of theoretical positions (Rubin, 1989; Weitzer, 2011; O’Connell-Davidson, 2002; O’Neill, 2010; Dewey \& Zheng, 2013; Sanders \& Hardy, 2014; Sanders et al, 2009). These include but are not limited to: the sociology of work and occupations whereby commercial sex is viewed as a kind of labour exchange relationship; third and fourth wave feminism (emphasising sexual rights and subjectivities) but also increasingly postcolonial or 'Third World' feminism (that points to the irrelevance in the global South of much feminist theorising) and where commercial sex is seen as a key route out of poverty for the women and men that participate in it (Kapur, 2007; Doezema, 2001; Agustín, 2007). Other critical feminist commentators have pointed to the ways that traditional feminist discourse has been co-opted within neo-liberal apparatuses of governmentality around labour and work, migration and security (Fraser 2013; Bernstein, 2007, 2010). Elizabeth Bernstein (2007) for example, argues that First World feminists have colluded in the maintenance of structures of control and domination exemplified in what she terms 'carceral feminism' which is a 'commitment of abolitionist feminist activists to a law and order agenda and a drift from the welfare state to the carceral state as the enforcement apparatus for feminist goals' (p.143).

In general, those theorists who view commercial sex as a form of work argue that it is the moral and social stigma associated with commercial sex and its ambiguous legal status in in a number of jurisdictions that makes it impossible for sex workers to work openly and without the threat of violence (see generally O’Neill, 2010; Weitzer, 2011). Consequently, these writers 
argue for sex workers' rights and statutory mechanisms that provide them with access to a range of state benefits such as health insurance and so forth. As Sanders et al. (2009) argue, this position opens up more possibilities for engaging reflexively with research subjects and for viewing commercial sex as a diverse range of practices that take place in a multitude of venues, with different opportunity structures and experiences of workers and clients. However, more fundamentally it acknowledges that many workers in the sex industry exercise agency and choice, and while few researchers are blind to exploitation and abuse, these need to be put on a continuum of experience that varies with the particular sector worked in; whether street or indoor based and the degree of social capital between workers and clients.

\section{$\underline{\text { Reflexivity in sex work research }}$}

Several issues permeate sex work research that have important implications for reflexivity in the research process (Hammond \& Kingston, 2014; Dewey \& Zheng, 2013; Ryan \& Huschke, 2015). First, there is significant disagreement about the actual object of study. The bulk of research in this area continues to be directed towards those forms of commercial sex that result in the direct exchange of sexual services for monetary or other compensation. However, in reality commercial sex spans a plethora of activities that include but are not limited to text, image and video pornography, live sex shows, strip and lap dancing clubs and other forms of adult entertainment (see Sanders \& Hardy, 2014). ${ }^{4}$ Even within those forms of commercial sex that depend on the direct (physical) exchange of sexual services for monetary compensation there is a huge variation between and within particular sectors (Weitzer, 2011; Shaver, 2005). For example, that which occurs on-street and off-street, but also in relation to female, male and transgender sex workers (Maginn \& Ellison, 2014; Mai, 2011). These issues are further complicated by the rise of the digital economy that has profound implications for both how we respond to and understand the nature of commercial sex in the $21^{\text {st }}$ century (Sanders, 2013).

Second, there is also the problem of how the narratives of sex workers are positioned to reflect their diverse experiences and voices (see Agustín, 2007; Dewey \& Zheng, 2013; O’Neill, 2010). While some in the neo-abolitionist feminist camp may well argue that they are engaging reflexively with research subjects and are giving voice to those women abused and traumatised by prostitution it nevertheless remains the case that the full range of voices and the different experiences of workers across the various sectors are rarely elucidated. This lack of contact with sex-working populations is partly reflected in theoretical and conceptual approaches to commercial sex that have tended to focus on how the researcher would like things to be rather than how things are. In other words, this estrangement from the subjects of study has led to 
claims being made about many facets of commercial sex that cannot withstand empirical scrutiny. Some of these claims are refracted through the domain of neo-abolitionist feminism itself. For instance, these perspectives have tended to eschew reflexive analyses of a complex subject matter to focus on samples of sex workers drawn from one particular strata (on-street) that is estimated to comprise only around 15 per cent of the total sex working population (Weitzer, 2011). Critics however, suggest that this body of research invariably self-selects the most extreme cases and constructs arguments against prostitution based on small samples of street-based sex workers who may have drug and alcohol dependency issues, experience high levels of violence from both clients and 'pimps' and who have multiple problems in their lives (Cojocaru, 2015; Weitzer, 2011).

The selection of particular cases designed to illustrate women's oppression means that neoabolitionists are placed in an awkward and contradictory position. On the one hand, feminism seeks to give voice to all individuals and all sectors of society, particularly those that are marginalised in patriarchal social structures (Butler, 1995; Rubin, 1989) and in many ways it was feminist versions of reflexivity that first drew attention to the power imbalances between researchers and their research subjects (Finlay, 2002). But on the other hand, selective inclusion only of those voices that align with the political position of neo-abolitionism undermines the reflexive impulse of feminism. Serious criticisms of unethical behaviour in dealing with (sex worker) research subjects have been levied at, for example, the prominent neo-abolitionist feminist Melissa Farley that resulted in a complaint being made to the American Psychological Association by a New Zealand sex workers' rights group (see Dewey, 2014 for a full discussion of this case). It is not the intention here to single Farley out for particular attention since this is a perennial problem, with some studies promoted by anti-prostitution advocates demonstrating biases, the use of unrepresentative sampling frames, ethical flaws and methodological inconsistencies (O’Neill, 2010; Weitzer, 2011; Ellison, 2015). Consequently, some researchers (Dewey \& Zhang, 2013; O’Neill, 2010; Shaver, 2005) and sex worker advocacy organisations (e.g. the Paulo Longo Research Initiative, the UK Network of Sex Work Projects) have argued for participatory action research that not only engages with the complex and diverse experiences of workers involved in all sectors of the industry and foregrounds the 'voice' of sex workers, but more generally advocates for 'ethical, interdisciplinary scholarship on sex work to inform activism and advocacy that will improve the human rights, health and wellbeing of sex workers' (Paulo Longo Research Initiative).

Finally, the issue of reflexivity is also problematised in terms of the effects of the research on the researcher. Some researchers have documented how studying commercial sex can take its 
toll on their sense of emotional wellbeing, their career and their professional reputation. For example, Hammond \& Kingston (2014) point out that as female researchers studying commercial sex they experienced what Goffman termed 'stigma by association' (Goffman, 1963) that had a profound impact both in their personal and professional lives. Similarly, as I describe below, Susann Huschke has outlined her experiences of conducting research into commercial sex in Northern Ireland in terms of 'emotional labour' that generated intense feelings of betrayal, anger and frustration (Ryan \& Huschke, 2015). My own particular difficulties led to a high degree of cynicism about Northern Irish politics in general, ${ }^{5}$ but also a sense of fatalism about the limits to which we as academics can ever hope to effect policy change.

\section{Researching commercial sex in Northern Ireland}

The difficulties that I experienced in researching commercial sex in Northern Ireland needs to be overlaid by two observations that go some way to contextualising the somewhat vitriolic response both to my own research and that of others (see Huschke et al, 2014).

The first concerns the relatively high level of church attendance and religiosity in the region generally (Tonge et al, 2014) and the permeation of religious-moral values into most aspects of social, political and cultural life in Northern Ireland. For example, it is only relatively recently that pubs and shopping centres have been allowed to open on a Sunday while the first international football match ever played in Northern Ireland on a Sunday occurred as recently as 2015. The second aspect concerns the ways in which the women's movement in Northern Ireland has been influenced by the legacy of religious morality and social conservatism. This reflects the view that 'gendered subjectivities formed within conservative societies will tend to develop a women's agenda that reflects society's religious values' (Ashe, 2006: 582). In Northern Ireland the alignment of one of the largest women's organisations - Women's Aid - with the DUP around the issue of prostitution / commercial sex can at least be partially understood by the relative lack of a third or fourth wave feminist tradition (until recently) that focuses on sexual rights and agency (Ashe, 2006; Fegan \& Rebouche, 2003).

The above provides the broad context to how my research was eventually perceived, but my particular interest in researching commercial sex was spurred while I was watching the early evening news in late 2012 when I saw the DUP's Lord Morrow talking eloquently about gender equality, sexual slavery and the human rights abuses of women who sold sex (men who sell sex have never been mentioned by the DUP). I was initially confused because the DUP had never shown any interest previously in commercial sex, nor arguably, in women's rights (Ritchie, 2015). In fact the Rev Ian Paisley, one time leader of the DUP and the Free Presbyterian Church 
had previously denounced prostitution as 'an activity which is illegal, sordid, degrading and biblically sinful [along with] with homosexual groups, paedophiles and drug dealers' (cited in Meredith, 2003). The DUP takes a particularly conservative line on a number of social issues including those affecting women and as the lawyer and feminist blogger, Wendy Lyon notes: 'The DUP remains one of the most socially conservative parties in Western Europe. It is fiercely opposed to abortion and LGBT rights, and advocates for the teaching of creationism in schools' (Lyon, 2015: 42). I was even more surprised when I learned that the DUP had elicited the support not only of Women's Aid in Northern Ireland, but also the Swedish radical feminist, Gunilla Ekberg who has been involved in a number of anti-prostitution campaigns globally.

The debate around sexual commerce in Northern Ireland led me to apply for research funding from the Leverhulme Trust - British Academy to study the policing and regulation of sexual commerce in four European cities (Prague, Berlin, Manchester and Belfast). The grant application was successful and after ethics approval had been obtained from my University I began the data collection, which was undertaken between 2013 and 2014. Since the earlier part of the research in England, Germany and the Czech Republic had been conducted without incident I had naively assumed that the same would hold for Northern Ireland. What I had not anticipated, given how uncontentious and unproblematic my research in the other three jurisdictions had been, was the extent to which the research evidence I gathered in Northern Ireland would be filtered through an ideological lens.

The very nature of 'evidence' and 'research' around commercial sex in Northern Ireland and how it was constituted became a site of considerable struggle and contestation. Indeed, what emerged from the parliamentary and media debates were 'hierarchies of evidence' (Nutley et al, 2012) with particular 'victim narratives' (Cojocaru, 2015; Andrijasevic, 2007) and 'autobiographical survivor stories' (Ryan \& Huschke, 2015) based on the accounts of 'survivors of prostitution' (e.g. see Moran, 2013) accorded a much higher status than evidence produced by researchers and academics. Unusually, in terms of what Becker (1967) termed a 'hierarchy of credibility' where those in power define the parameters of the debate, even 'evidence' from official sources such as the police and NI Department of Justice was downplayed to favour that which was based on feeling and emotion, particularly from a number of advocacy groups. Lord Morrow had a very public spat with a senior PSNI officer claiming that he was 'meddling' after the latter gave a media interview in which he suggested that the proposed legislation would be impossible to enforce (Telford, 2013). In another example, at one of the Justice Committee hearings the DUP's Mr Jim Wells bizarrely accused senior officials from the Department of Justice of having clandestine meetings with representatives of the sex industry in order to 
undermine Lord Morrow's Bill (Northern Ireland Assembly, 2014: 14-16). ${ }^{6}$ A cursory analysis of the Hansard parliamentary reports covering the debates in the Northern Ireland Assembly around Lord Morrow's Bill notes at least sixteen separate occasions whereby various DUP MLAs made the claim that research evidence on the issue of commercial sex in Northern Ireland was not needed and as Lord Morrow himself suggested:

I always said that additional research was unnecessary. The basic issue with which we need to engage is not more scholarship but answering the question, do we think that selling sex is ever an appropriate form of work in $21^{\text {st }}$ century Northern Ireland (Morrow, 2014a).

For the uninitiated this of course could be construed to mean that there was already a large pre-existing evidence base around commercial sex in Northern Ireland from which such a position could be legitimated. This would be untrue: no such empirical research existed. There were no data to indicate the size of the sex working population, the demographics of sellers and buyers, the sexual orientation of sex workers, the role of migration into the sex industry on the island of Ireland facilitated by a porous land border, nor indeed about the changing topography of commercial sex due to the digital economy. Aside from an excellent historical account of prostitution in Belfast from the $19^{\text {th }}$ century (McCormick, 2009) there have only been two other academic studies of commercial sex in the region: one by myself (Ellison, 2015) and the other commissioned by the NI Department of Justice (Huschke et al, 2014). Both these studies elicited the views and opinions of those most affected by both existing and proposed legislation - sex workers themselves. In spite of Lord Morrow's stated concerns for the welfare of sex workers he did not actually speak to any to ascertain what the effects of his Bill might have on their lives (Meredith, 2015).

\section{Determining the size of the commercial sex sector in Northern Ireland}

I have written elsewhere (Ellison, 2015) that the debate about commercial sex and trafficking for sexual slavery in Northern Ireland bears all the hallmarks of a moral panic as famously articulated by Stan Cohen in his Folk Devils and Moral Panics (Cohen, 1972). But to what extent are these public and media concerns about prostitution and trafficking for sexual exploitation justified? This is important because the 'evidence' marshalled by the DUP and other advocacy groups based their support for a sex-purchase ban on the fact that 'thousands' of women may be involved in the 'sex slave trade' and that trafficking for sexual exploitation was rife in Northern Ireland (Poole, 2012). However, both my own research and that of Huschke et al. (2014) concluded that the commercial sex sector in Northern Ireland is comparatively small and certainly much smaller than other UK jurisdictions and internationally. Because of the 
violent socio-political conflict that erupted between 1968 and 1994 Belfast never had a particularly active street scene like some other UK cities such as Glasgow, Birmingham, Manchester and Liverpool owing to the inherent dangers of using public space, particularly at night. From the start of the peace process in the mid-1990s a small street-sector once again emerged in Belfast, but the representative from the Belfast Health and Social Care Trust (that provides sexual health advice and screening to street-based workers) told me that there were only around 20-30 street-workers based mainly in Belfast, although fewer than 5 are available on a day to day basis (Ellison, 2015; Huschke et al, 2014). Nearly all street-based workers are from Northern Ireland and their ages range from 30-55 years. A small number of male street-based sex workers also operate in Belfast in the vicinity of a number of gay bars and clubs (Maginn \& Ellison, 2014).

In terms of the indoor off-street sector I was given access to anonymised data from one of Ireland's largest escort websites (Escort Ireland) for a five-year period (2009-2013). This data suggested that each year around 600 sex workers registered with Escort Ireland as providing sexual services in Northern Ireland. However, because some sex workers only work for specific periods and some tour between cities in Ireland and the UK, only around 40-60 are available in Northern Ireland on any given day. Of course, Escort Ireland represents only one of a range of potential escorting websites in Northern Ireland. In a separate study by Huschke et al (2014) data scraping techniques were used to survey a number of free and commercial websites (Adultwork, Gay Swap, Backpage, Escort Ireland, Craigslist etc.) on seven random days during a particular month. The researchers' concluded that when these numbers are aggregated around 300-350 female, male and transgendered escorts offer commercial sexual services in Northern Ireland on a daily basis.

Out of all the cities studied as part of my British Academy - Leverhulme Trust research study Belfast had by far the smallest commercial sex sector, and I concluded that the on-street sector in Manchester (England) is as large as the indoor and on-street sectors combined in Northern Ireland. In relation to trafficking for sexual exploitation into Northern Ireland there have only been two prosecutions for this offence since 2009 (though neither case resonates with conventional media narratives around trafficking) and as Huschke et al (2014: 127) suggest 'we found that the number of trafficked victims into the Northern Ireland sex industry is low and that the majority of people selling sexual services are not trafficked'.

The wrong kind of evidence 
Many academics, the Police Service of Northern Ireland (PSNI) and the NI Department of Justice were opposed to Clause 15 of Lord Morrow's Bill. Some activist groups were also opposed, including notably, the Belfast Feminist Network (BFN). The BFN is a recently established network of over 1,000 feminist activists that seek to engage with broader questions of sexuality, sexual rights and the relationship between religion and gendered attitudes in NI. In its written submission to the NI Justice Committee the BFN made clear its position that Lord Morrow's Bill would likely increase, not decrease the risks to sex workers and that the cartography of sexual commerce was much more diverse than that depicted by Lord Morrow and Women's Aid (Belfast Feminist Network, 2013). In particular, the BFN raised issues that were not acknowledged by the DUP nor Women's Aid: namely that the debate about commercial sex in NI has been heteronormative - focusing exclusively on male buyers and female sellers and that the Bill essentialised the purchase of commercial sex as a purely exploitative relationship.

While arguably the BFN represents a broader spectrum of female opinion in Northern Ireland, their evidence was not acknowledged by the DUP and it was only Women's Aid whose evidence on behalf of women was taken into account in the legislative process. For my own part, in 2013 I published a letter in the Belfast Telegraph (one of Northern Ireland's largest circulation newspapers) pointing out that Lord Morrow's Bill was incorrect in painting a direct link between commercial sex and human trafficking and on the basis of my preliminary research findings I suggested that there was no evidence that a sex purchase ban would have an impact on human trafficking and that the legislation may well have downstream consequences in terms of increasing the risks of violence to sex workers. I did not at any stage suggest that abuse and exploitation were absent from the sex industry; rather I suggested that working in the sex industry had to be viewed on a continuum of experience. I followed this letter up with a longer op-ed in the Belfast Telegraph where I expanded on some of my research findings in more detail. It is important to point out that at no stage did Lord Morrow or anyone else in the DUP contact me to speak about my research, and in fact the Party did not reply to numerous telephone and email requests to be interviewed in connection with the study.

In September 2013, the Swedish anti-prostitution activist and radical feminist Gunilla Ekberg gave evidence in support of Lord Morrow's Bill to the NI Justice Committee and sat alongside Lord Morrow and Dr Dan Boucher from Christian Action Research Education (CARE). ${ }^{7}$ Ms Ekberg had been a frequent visitor to Belfast and had participated in several media appearances with Lord Morrow during the launch of his Bill. During the questioning session Ms Ekberg claimed without citing any evidence that 'the academic world in the UK is particularly pro-prostitution compared to other countries' and that '97 per cent of women' were coerced or 
forced into prostitution (Northern Ireland Assembly, 2013). Similarly, Dr Dan Boucher from CARE positioned the role of research as a simple matter of weighing up two positions and basing a decision on their moral worth; the moral worth in this case being on the side of those who oppose prostitution (Northern Ireland Assembly, 2013). However, as O’Connell Davidson (2013) pointed out in her own written evidence to the NI Justice Committee, Dr Boucher appeared not to understand:

...the relationship between theory, value and evidence in social scientific research... [and] oversimplifies the positions that different academics take on the issue of prostitution. It is possible to approach prostitution as both a form of work and a site of exploitation' (p.2. Italics in original).

For Weitzer (2010) the claims made by some advocacy groups and political actors in relation to the debate about commercial sex are based on what he terms 'prescientific reasoning' (p.15). Such claims are made in the absence of evidence and more importantly cannot be demonstrated as falsifiable. In this sense Dr Boucher neglected to consider the Popperarian dimensions to scientific / social scientific inquiry where research hypotheses are tested and where the research process is conducted not in line with some preconceived ideological driver or motivation but on the basis of the available empirical evidence (Popper, 2002).

Of course, none of this is to imply that there is necessarily some underlying 'truth' waiting to be discovered in the research process and indeed the notion of reflexivity has been used to good effect to challenge certainty in the social sciences, pointing to the vast array of meanings that people use to make sense of their lives (Alvesson \& Sköldberg, 2009). Nevertheless, some critics have suggested that reflexive research poses particular challenges as well as opportunities. Finlay (2002) for example, describes how researchers can navigate some of these difficulties since for her reflexive research can come to represent a kind of postmodern bricolage where researchers have to:

...negotiate the "swamp" of interminable self-analysis and self-disclosure... On their journey they can all too easily fall into the mire of the infinite regress of excessive selfanalysis and deconstructions (p. 212).

For Finlay (2002) researchers should strive to keep their focus on the research participants and consider the ways that their research can contribute to new knowledge and understanding. In this sense it might be argued that if criminology and indeed other social scientific disciplines are to have any purchase outside of the academy they must also have a relevance to policy formulation 
by adopting rigorous and appropriate methodologies, deliberating on and analysing various sources of data, and presenting the evidence itself in a way that exposes a range of possibilities. What this means - and of course it is easier said than done - is that social scientists must strive to ensure that their research is comprehensive, reliable and adhere to the canon of replicability as well as demonstrating transparency in the research process.

\section{The religious right meets feminism in Northern Ireland}

The level of co-operation between Ms Ekberg and the DUP was striking, although not particularly unusual since several commentators have documented what they perceive as a growing conservative and right-ward shift by a section of the feminist movement in the United States (Bernstein, 2007, 2010; Zimmerman, 2012). I decided to send Ms Ekberg an email inquiring into the alignment of herself as a radical feminist with a party of the Christian right. I specifically asked whether she shared the DUP's view of homosexuality as 'repulsive, ${ }^{8}$. I was aware of the nature of the 'sex wars' in the US, but I could not really see what feminism or the feminist movement stood to benefit or gain from this relationship given that this alignment appeared to privilege the Christian right more than radical feminists particularly in the case of Northern Ireland where the DUP hold significant political power and have used it in the past to limit women's rights and non-heteronormative relationships (Ritchie, 2015; Meredith, 2003; 2015).

My email to Ms Ekberg was intended as a personal not a professional one and its tone, on reflection, was a bit ill-considered. However, I was not hostile or rude to her and I pointed out that I would have more in common with radical feminists rather than the DUP on most social issues. I pointed out that the incessant homophobia emanating from the DUP created such an aura of stigma among LGBT youth that it could potentially lead to suicide, a finding of a recent NI study (O'Hara, 2013), and I also pointed out that the DUP's atrocious record on women's rights. Ms Ekberg did not reply to my email but it nevertheless ended up in the hands of Lord Morrow and was to come back to haunt me at the NI Justice Committee in January 2014 which I describe below.

\section{The Spanish Inquisition}

In 2013 I submitted written evidence to the NI Justice Committee in respect of Lord Morrow's Bill while my colleague at Queen's University, Dr Susann Huschke did the same. Our submissions were based on our respective research into commercial sex in Northern Ireland. For my own part I kept my submission as descriptive and factual as possible: I included prevalence 
figures for the size of the commercial sex sector (see above), demographic characteristics of sex workers as well as a short description of the role of the digital economy in purchasing and selling sex, as well as the difficulties faced in transposing a policy designed for one jurisdiction (Sweden) to another (Northern Ireland) given the vastly different social, political and cultural context of the latter.

In early January 2014 I was surprised to be telephoned by an official from the NI Justice Committee asking me if I would give oral evidence to the all-party Justice Committee later that month. I had not expected to be asked to give evidence since I had already submitted a lengthy written submission. In hindsight I feel that I was asked to attend the Committee hearing so that the DUP could produce my email to Ms Ekberg and creating a public opportunity to demonstrate my 'bias' and in so doing undermine the research that I had conducted. As it turned out myself and Dr Huschke presented our evidence at the same session. I spoke first and from the outset I was slightly irritated by the fact that most of the DUP members were not paying the slightest bit of attention to anything I had to say and were twiddling with their mobile phones, or browsing on their laptop computers. The floor was then opened up to the committee members and the DUP MLA Mr Jim Wells went first and produced the email that I had sent to Ms Ekberg. He claimed that I was anti-DUP (correct in the sense that I fundamentally oppose their social policies), and argued (less convincingly in light of later developments) that the party was not homophobic and that there was no relationship between anything the DUP said against the LGBT community and incidences of suicide among LGBT youth. One commentator described our experience thus: 'Researchers Graham Ellison and Susann Huschke were subjected to an interrogation so aggressive that a Sinn Féin member told them they "might know what the Spanish Inquisition was like by the time you leave here today"' (Lyon, 2015: 43). The DUP's questioned whether we were spokespersons for 'pimps' and 'traffickers' since both of us had used data from an online escort website (in determining prevalence figures). The Chair of the Committee, the DUP's Mr Paul Givan, also demanded that I name my interview respondents for the study, something which I refused to do. At the end of the session Mr Givan told me that he was reporting me to my University for making negative comments about the DUP.

A month after the Justice Committee evidence hearing two Freedom of Information Requests were lodged to access my email correspondence. The first was submitted to Queen's University asking for all my email correspondence for the period of one year that mentioned any of the following terms: Swedish Model, Prostitution, Human Trafficking, Sexual Trafficking, Commercial Sex, Sex Worker, Prostitute. This generated several thousand emails, but any email that related to my research or that was between myself and a respondent was redacted under the 
University's research governance regulations and the condition of anonymity and confidentiality granted to research participants. This was an extremely time consuming exercise and meant that over a week was dedicated to sifting through email correspondence. The second was submitted to the Northern Ireland Department of Justice asking for all copies of email correspondence that I and other organisations and individuals had with them regarding Lord Morrow's Bill. In both cases I felt that the Freedom of Information request was simply a fishing expedition to find out who I had interviewed for the study and that it was related to Mr Givan's request at the Justice Committee for me to name my respondents.

Laura Lee (a Glasgow based sex worker) and Lucy Smith from UglyMugs.ie (an organisation that campaigns to end violence against sex workers) experienced by their own accounts extreme levels of hostility in their questioning by DUP members on the Justice Committee. As Ms Lee notes, the DUP's Paul Givan '...felt that it was appropriate to quiz me about my personal sex life, my relationship with my dad and he also alleged that I target vulnerable disabled men' (cited in Lyon, 2015: 42). Ms Lee was also forced by Mr Wells to give her real name as opposed to her working name on the live video stream, while at other Committee sessions so-called 'survivors of prostitution' were treated to the privilege of incamera hearings and given a guarantee of anonymity by the Justice Committee. Similarly, Lucy Smith was aggressively questioned on her connection to an escort website that Uglymugs.ie advertises on, and was not asked by any DUP members about sex worker safety or the potential implications of Lord Morrow's legislation for violence experienced by sex workers (Lyon, 2015).

Given that the Committee session was being broadcast live via webcam the media quickly became interested in my comments about homophobia in the DUP ignoring the point in my email questioning the consistency of a feminist/DUP alliance. In relation to the DUP's complaint ${ }^{9}$ about me to my University, Queen's saw this as an issue of academic freedom and were fully supportive of me and at one point considered advising academics not to participate with NI Assembly Committees if they were going to be subjected to the kind of questioning that myself and Dr Huschke faced. I was inundated with hundreds of emails of support from colleagues, students, young LGBT people who had left Northern Ireland because of homophobia, random members of the public and even DUP party members! I was contacted by a senior DUP official and told that Mr Wells and Mr Givan had been reprimanded, though I suspect more for their treatment of Laura Lee since even in the macho world of Northern Irish politics, the DUP has limits about so aggressively and publicly attacking a lone female. The senior party official told me that they 'wanted the story to die' since all Mr Wells and Mr Givan had managed to do 
was once again raise the spectre of homophobia within the DUP. The party hierarchy removed Mr Givan as Chair of the Justice Committee several months later for unspecified reasons while Mr Wells was later forced to resign as Minister for Health following comments he made about homosexuality (Belfast Telegraph, 2015).

I fully accept that my email to Ms Ekberg created the impression among the DUP that I was a biased source, and gave them the ammunition to attack me that they had sought all along. But had anyone in the DUP asked what my views on the party's social policies were I would have had no hesitation telling them. Nevertheless, at no stage during the Justice Committee hearing was I asked any questions about what my research had uncovered by the DUP members despite being at that time only one of two people in Northern Ireland who had spoken to sex workers about the possible effects of the sex-purchase legislation on their lives. Indeed, Susann Huschke, the only other researcher to have drawn in views of sex workers themselves, was later subjected to wide-ranging criticism from DUP politicians, Women's Aid and a section of the Northern Irish media following the publication of her own research into commerical sex in Northern Ireland (see Huschke et al, 2014). Among other things Huschke was accused of being a member of the 'pimp lobby' and that her methods and analytical approach demonstrated 'judgemental bias’ (Ryan \& Huschke, 2015: 9). Huschke has subsequently written of her experiences in terms of the emotional labour it demanded from her as a researcher but also as an individual. As she explains:

The most frustrating part was trying to discuss this topic with people who very clearly do not know much about research and methodology - and why would they, it is not their area of expertise - but come up with the most unfounded accusations that aim to destroy the research by making it look unprofessional... There was no way of explaining our methods and the research process to people like Paul Givan and Jim Wells (DUP representatives in the Justice Committee). They had made their minds up a long time ago about what sex work is and what is to be done about it, and were not going to be swayed by anything that we found in our study, or by anything sex workers themselves had to say about it (cited in Ryan \& Huschke, 2015: 10).

\section{Conclusions}

In this chapter I have revisited my own experience and the general climate of conducting research into the highly controversial topic of commercial sex in Northern Ireland. Undoubtedly this research would have been controversial in any event but it was made much more so because the research itself intersected with political debates around the introduction of sex-purchase 
legislation by the DUP. Consequently, my research was perceived by the DUP as a direct attack on the proposed legislation and every attempt was made to attack my credibility as someone who was hostile to the Party.

Developments in Northern Ireland call into question the nature of 'evidence' and the purposes for which it can be used and abused. The number of DUP politicians who claimed that evidence on the nature of commercial sex was irrelevant suggests that evidence-based policy is a long way from becoming embedded as a value in the political process in Northern Ireland, which in part is due to the relative newness of the political institutions established there. ${ }^{10}$ Empirical evidence from research into commercial sex was either ignored or treated as inferior to that conducted by a number of advocacy groups which was based normatively on feelings, emotions and particularistic moral stances. As Lord Morrow himself notes: 'For me, taking action was very much motivated by my Christian faith and principles. I am not ashamed to say so' (Morrow, 2014b). I have no particular objection to Lord Morrow's Christian principles, but what I do have an objection to is the way in which these principles are accorded a particular status within the Northern Irish policy arena and to imply that other sources of evidence are significantly less worthy. There are a number of prominent DUP politicians who argue that laws should be formulated according to a literal interpretation of the Bible (Tonge et al, 2014: 10). However, it is debatable whether this is either a practical or an acceptable basis for policy-making in the $21^{\text {st }}$ century.

However, a more fundamental concern relates to the alignment of a section of the feminist movement with the Christian right. I have suggested in this chapter that this alliance needs to be viewed problematically and has benefitted more the Christian right that women generally. In the context of Northern Ireland it could be argued that the alignment of Ms Ekberg and Women's Aid with the DUP has however inadvertently, set back not advanced, the position of women in Northern Ireland and those from LGBT backgrounds. In particular, the 'winning' this particular battle only served to embolden the DUP to tackle what they perceived as other longstanding issues: namely that of abortion / reproductive rights and LGBT equality. No sooner had the ink dried on Lord Morrows Bill (it was passed in December 2014) than Mr Jim Wells was proposing amendments to the forthcoming NI Justice Bill to tighten Northern Ireland's already restrictive abortion laws even further by imposing a mandatory prison sentence of ten years on a women who procured a medical abortion in a private clinic in Northern Ireland (Teggart, 2014). Around the same time the DUP's Mr Paul Givan also launched a campaign to introduce what he termed a 'conscience clause' in LGBT equality legislation that would make it legal to discriminate against members of the LGBT community on the grounds of religious belief (Kane, 2014). It is in this 
sense that I would caution a section of the feminist movement to be very careful in what you wish for.

\footnotetext{
${ }^{1}$ I use commercial sex or sex work in preference to prostitution in this paper since the former is arguably a more reflexive and less stigmatising term than the latter. However, where I refer specifically to legislation or official policy I use the term prostitution.

2 The Policing and Regulation of Sexual Commerce: A Four-City Case Study, British Academy Leverhulme Trust (2013). Graham Ellison was PI on the project, Ron Weitzer Was CI. Ellison was solely responsible for the data collection in Manchester and Belfast.

${ }^{3}$ The earlier terminology of the Bill was criticized for implying that only women sell sex. In the version that was legislated for the terminology adopted was more gender neutral.

${ }^{4}$ Since the legislation passed by the Northern Ireland Assembly is mainly geared to criminalising commercial sex between consenting adults this is the aspect of sexual commerce that I focus on in this chapter.

${ }^{5}$ In something indicative of this, some political parties in Northern Ireland told me in the course of my interviews that Lord Morrow's Bill was deeply flawed, but also added that they would be voting for it anyway 'because there are no votes in prostitutes'.

${ }^{6} \mathrm{~A}$ subsequent investigation revealed that $\mathrm{Mr}$ Wells accusations against Department of Justice officials were entirely spurious.

${ }^{7}$ A London-based fundamentalist Christian lobbying group.

${ }^{8}$ Several DUP party members have made homophobic statements. For example, Ian Paisley Jnr famously claimed that he was 'repulsed' by homosexuality (BBC, 2007).

${ }^{9}$ From what I was told a telephone complaint was made by Mr Givan to Queen's University's Director of Communications.
}

\section{BIBLIOGRAPHY}

Agustín, L.M. (2007) Sex at the Margins: Migration, Labour Markets and the Rescue Industry, London: Zed books

Alvesson, M. \& Sköldberg, K. (2009) Reflexive Methodology, London: Sage

Andrijasevic, R. (2007) 'Beautiful dead bodies: gender, migration and representation in antitrafficking campaigns', Feminist Review, 86, pp.24-44

Ashe, F. (2006) 'The Virgin Mary Connection: Reflecting on Feminism and Northern Irish Politics', Critical Review of International Social and Political Philosophy, Vol 9 (4) December, 573-588

Barry K., (1995), The Prostitution of Sexuality, New York: NYU Press

BBC (2007) 'Row over "repulsive gays" comment', BBC News, Wednesday 30th May. Available: http://news.bbc.co.uk/1/hi/northern ireland/6705637.stm (Accessed 8th April, 2016). 
Becker, H. (1967) ‘Whose side are we on?’, Social Problems, Vol 14 (3) 234-47

Belfast Telegraph, (2015), 'DUP Minister Jim Wells quits after gay abuse controversy', $27^{\text {th }}$ April. Available: http://www.belfasttelegraph.co.uk/news/politics/dup-minister-jim-wellsquits-after-gay-abuse-comments-controversy-31173893.html

Belfast Feminist Network (2013), Evidence to Committee for Justice: Trafficking \& Exploitation (Further Provisions and Support for Victims) Bill. Committee for Justice, Belfast: Northern Ireland Assembly

Bernstein, E. (2010) 'Militarised humanitarianism meets carceral feminism: The politics of sex, rights and freedom in contemporary anti-trafficking campaigns', Signs: Journal of Women in Culture and Society, Vol 36, No 1, pp45-71.

Bernstein, E., 2007 'The Sexual Politics of the "New Abolitionism"', Differences: A Journal of Feminist Cultural Studies 18: 5, 128-151

Butler, J. (1995) 'Contingent Foundations' in Seyla Benhabib et al., Feminist Contentions: A Philosophical Exchange, New York: Routledge, pp. 35-58

Cohen, S. (1972). Folk Devils and Moral Panics. (1 ${ }^{\text {st }}$ edition) St Albans: Paladin

Cojocaru, C. (2015) 'Sex trafficking, captivity, and narrative: constructing victimhood with a goal of salvation', Dialectical Anthropology, June, Vol 39 (2), 183:194

Dewey, S. (2014) 'Anthropological Research With Sex Workers: An Introduction', Chapter 1 in Dewey, S. \& Zheng, T. (2013) (Eds) Ethical Research with Sex Workers, Springer

Dewey, S. \& Zheng, T. (2013) (Eds) Ethical Research with Sex Workers: Anthropological Approaches, Springer

Doezema, J. (2001) 'Ouch! Western Feminists' "Wounded Attachment" to the "Third World Prostitute', Feminist Review, No 67, Spring, pp. 16-38

Ekberg, G. (2004) 'The Swedish law that Prohibits the Purchase of Sexual Services', Violence against Women, Vol 10, No. 10, pp1187-1218

Ellison, G. (2015) 'Criminalizing the Payment for Sex in Northern Ireland: Sketching the Contours of a Moral Panic', British Journal of Criminology, DOI: 10.1093/bjc/azv107

Farley, M., Bindel, J., \& Golding, J.M. (2009) Men who Buy Sex: Who they Buy and What They Know, Eaves: London

Fegan, E.V. \& Rebouche, R. (2003) 'Northern Ireland's Abortion Law: The Morality of Silence and the Censure of Agency', Feminist Legal Studies, 11, 221-254

Finlay, L. (2002) 'Negotiating the swamp: the opportunity and challenge of reflexivity in research practice', Qualitative Research, 2 (2), 209-230 
Fraser, N. (2013) Fortunes of Feminism: From State-managed Capitalism to Neoliberal Crisis, London: Verso Books

Goffman, E. (1963) Stigma, London: Penguin

Hammond, N. \& Kingston, S. (2014), 'Experiencing Stigma as Sex Work Researchers in Professional and Personal Lives,', Sexualities, March. 17 (3), 329-347

Huschke, S., Shirlow, P., Schubotz, D., Ward, E., Probst, U., \& Ní Dhónaill, C. (2014) Research into Prostitution in Northern Ireland, Belfast: Department of Justice Northern Ireland

Jeffreys, S. (2008) The Idea of Prostitution, Melbourne: Spinifex Press

Kapur, R. (2007) 'Faith' and the 'good' liberal: The construction of female sexual subjectivity in anti-trafficking legal discourse', Chapter 10 in V.E. Munro \& C.F. Stychin (Eds) Sexuality and the Law: Feminist Engagements, London: Routledge

Kane, A. (2014), 'Paul Givan: Conscience Clause MLA - a politican on a mission', Belfast Telegraph, 20th December. Available: http://www.belfasttelegraph.co.uk/life/paul-givanconscience-clause-mla-a-politician-on-a-mission-30850887.html

Levy, J. (2014) Criminalising the Purchase of Sex: Lessons From Sweden, London: Routledge

Lyon, W. (2015) 'Ireland: Clause 6', Albertine, July. pp.40-43. Available: https://www.academia.edu/15363926/Ireland_Clause_6

Maginn, P. \& Ellison, G. (2014) 'Male Sex Work in Northern Ireland and the Irish Republic', in Minichiello, V. \& Scott, J. (2014) Eds. Male Sex Work and Society, New York: Harrington Park Press

Mai, N. (2011) 'Tampering with the Sex of "Angels": Migrant Male Minors and Young Adults Selling Sex in the EU', Journal of Ethnic and Migration Studies, No 37, No 8 pp1237-1252

McCormick, L. (2009) Regulating Sexuality: Women in Twentieth Century Northern Ireland, Manchester: Manchester University Press

Meredith, F. (2003) 'Fear and Loathing: The Religious Right's view of women is fuelled by hatred', The Guardian, $3^{\text {rd }}$ August.

Meredith, F. (2015) 'Strait-laced DUP has always been funny about sex' The Belfast Telegraph, $1^{\text {st }}$ May.

Moran, R. (2013) Paid For - My Journey Through Prostitution: Surviving a Life of Prostitution and Drug Addiction on Dublin's Streets, London: Gill \& Macmillan 
Morrow, Lord (2014a) 'Briefing Note: Briefing on Clause 6 - Full Response to DOJ Research’ Belfast: Democratic Unionist Party: Belfast.

Morrow, Lord (2014b) Human Trafficking and Exploitation (Criminal Justice and Support for Victims) Bill: Final Stage, Belfast: Northern Ireland Assembly. Available: They Work for You: http://www.theyworkforyou.com/ni/?id=2014-12-09.4.1

Northern Ireland Assembly (2013), Official Report (Hansard), Human Trafficking \& Exploitation (Further Provisions and Support for Victims) Bill, Briefing from Lord Morrow MLA, CARE, Former Swedish Government Special Advisor, $12^{\text {th }}$ September. Belfast: Northern Ireland Assembly

Northern Ireland Assembly (2014a), Committee for Justice, Official Report (Hansard), Human Trafficking and Exploitation (Further Provisions and Support for Victims) Bill: Department of Justice, Minutes of Evidence, $6^{\text {th }}$ March.

Nutley, S., Powell, A., \& Davies, H. (2012) 'What counts as good evidence?', November. Research Unit for Research Utilisation (RURU), Available:

https://www.nesta.org.uk/sites/default/files/what_counts_as_good_evidence_provocation_ paper.pdf

O'Neill, M. (2010). 'Cultural Criminology and Sex Work: Resisting Regulation Through Radical Democracy and Participatory Action Research', Journal of Law and Society, Vol 37 No 1, pp210-232.

O’Connell Davidson, J. (2013) 'The Human Trafficking and Exploitation (Further Provisions and Support for Victims) Bill, Written Evidence in respect of Clause 6. Available: http://www.niassembly.gov.uk/globalassets/Documents/Justice/human-traffickingbill/written-submissions/Professor-Julia-OConnell-Davidson.pdf (Accessed 7th April, 2016).

O'Connell Davidson, J. (2002) 'The Rights and Wrongs of Prostitution', Hypatia, Vol 17, No 2, Spring. pp84-98

O'Hara, M. (2013), Through our Minds: Exploring the Emotional Health and Wellbeing of Lesbian, Gay, Bisexual and Transgender People in Northern Ireland, Belfast: The Rainbow Project

Poole, A (2012) 'Sex Slaves Suffer rapes 300,000 times a year in Ulster', February $15^{\text {th }}$. The Daily Mirror (Irish Edition). Available:

http://www.thefreelibrary.com/Sex+slaves+suffer+rapes+300,000+a+year+in+ Ulster..+INVESTIGATES...-a0280054501 (Accessed 12 th August, 2015).

Popper, K. (2002), The Logic of Scientific Discovery, London: Routledge

Ritchie, M. (2015), 'Why a DUP coalition would be dangerous for women', The Telegraph, $30^{\text {th }}$ April. 
Ryan, P. \& Huschke, S. (2015) 'Conducting Sex Work Research in a Politically Contentious Climate: Lessons from Ireland', In: I. Crowhurst, A. King, \& A.C. Santos (eds.) Sexualities Research: Critical Interjections, Diverse Methodologies and Practical Applications, Routledge: London.

Rubin G, (1989) 'Thinking sex: notes for a radical theory of the politics of sexuality', in Pleasure and Danger: Exploring Female Sexuality Ed. C Vance, London: Pandora

Sanders, T. (2013) Paying for Pleasure: Men Who Buy Sex, London: Routledge

Sanders, T and Hardy, K (2014) Flexible Workers: Labour, Regulation and the Political Economy of the Stripping Industry, London: Routledge

Sanders, T., O’Neill, M and Pitcher, J (2009) Prostitution: Sex Work, Policy and Practice, London: Sage

Scoular, J. (2004) 'Criminalising "Punters": Evaluating the Swedish position on prostitution', Journal of Social Welfare and Family Law, 26 (2), 195-210

Shaver, F. (2005) 'Sex Work Research: Methodological and Ethical Challenges', Journal of Interpersonal Violence, March., 20 (3), 296-319

Teggart, G., (2014) 'It's time Northern Ireland put an end to the climate of fear around abortion', New Statesman, 28th November. Available:

http://www.newstatesman.com/politics/2014/11/it-s-time-northern-ireland-put-endclimate-fear-around-abortion (Accessed 7th April, 2016).

Telford, L. (2013) 'DUP man Lord Morrow hits out at PSNI “meddling” over Prostitution Bill', The Belfast Telegraph, 23rd September, Available:

http://www.belfasttelegraph.co.uk/news/northern-ireland/dup-man-lord-morrow-hits-outat-psni-meddling-over-prostitution-bill-29598199.html (Accessed 7th April, 2016).

Tonge, J. Braniff, M., Hennessey, T., McAuley, J.W. \& Whiting, S. (2014) The Democratic Unionist Party: From Protest to Power, Oxford: Oxford University Press

Weitzer, R. (2011) Legalising Prostitution: From Illicit Vice to Lawful Business, New York: New York University Press

Weitzer, R. (2010), 'The Mythology of Prostitution: Advocacy Research and Public Policy', Sex Research and Social Policy, 7: 15-19

Weitzer, R. (2006), ‘Moral Crusade Against Prostitution', Society, March/April. 33-37

Zimmerman, Y. (2012) Other Dreams of Freedom: Religion, Sex and Human

Trafficking, Oxford University Press 
10 While the political institutions were established in 1998, in reality it is only since 2007 that they became operational when Sinn Fein decided to take their seats. 